\title{
University censured over research accounting
}

Quebec. Quebec's main research funding agency has joined its federal counterpart in suspending grants to Concordia University and demanding the return of money which has been 'improperly' used, following an audit of the university's engineering and computer science faculty.

The federal body, the Natural Sciences and Engineering Research Council(NSERC), has asked the Royal Canadian Mounted Police to investigate the irregularities. Both reinforce claims by an engineering professor convicted of shooting four academic colleagues that work pressures and malprac- tice in his department contributed to his actions (see Nature 370, 166; 1994).

The Fonds pour la Formation de Chercheurs et l'Aide a la Recherche (FCAR) said last week that before it will lift the suspension the university must show that it has introduced suitable management measures. The agency provides Concordia with grants worth more than $\mathrm{C} \$ 2$ million a year.

The FCAR is an autonomous agency of the provincial education department, and was set up in 1984 to promote the scientific and technological development of Quebec. Its grants total about $C \$ 50$ million a year.

\section{India bans the use of sex screening tests}

New Delhi. The Indian parliament last week passed a bill banning the use of prenatal tests to detect the sex of unborn children. Doctors who perform the so-called 'sex determining tests' (SDTs) for selective abortion of female fetuses - as well as women who demand them - face up to three years in jail and Rs10,000 (US\$323) fine.

The move is intended to check a rapid increase in the killing of female fetuses in a country where girls are still considered a financial burden because of the dowry that has to be paid when they marry. This can range from a few thousand rupees in middle-class families to several hundred thousandrupees in the mostaffluent social groups.

India's liberal abortion laws, as well as the general availability of SDTs since the late $1970 \mathrm{~s}$, have together provided a way out of the dowry problem. For as little as Rs500, the private clinics that have sprung up all over the country offer a service using ultrasound, amniocentesis and chorionic villus sampling techniques. Official figures are not available, but voluntary organizations claim that between 50,000 and 80,000 female fetuses are aborted every year after the sex test.

According to the 1991 census, the sex ratio has fallen to 929 women for every 1,000 men, compared to 972 women in 1901. Selective abortions, increasing every year, might distort the sex ratio even more.

The legislation is intended to curb this threat by halting the rapid growth of sex clinics, and making women's access to them difficult. In future, sex tests will only be allowed in certain laboratories and licensed private clinics where there are suspected cases of inherited and sex-linked diseases. Doctors who perform such tests for any other reason will be debarred and prosecuted.

But opponents of the ban doubt whether the law will be rigorously enforced. "The legislation will simply drive the practice underground and quacks will take over from law-abiding practitioners," says Kiren
Kucheria, who introduced amniocentesis in the early 1970s at the All India Institute of Medical Sciences in Delhi.

Critics point out that, despite the antidowry law, some 2,500 brides are murdered every year for not bringing enough dowry. And in Maharashtra state, which banned the SDT in 1988, these tests are still available illegally.

Feminist groups have welcomed the legislation, but they have reservations, arguing that a woman who takes an SDT

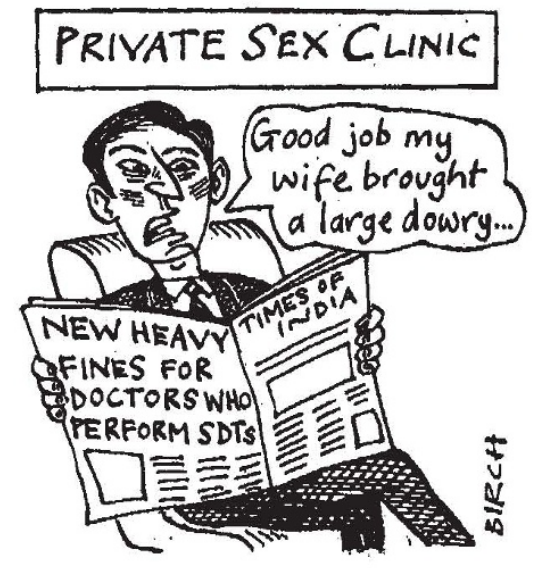

should not be punished, as the decision to undergo the test is usually that of her family.

Critics are also unhappy that the law says nothing about the use of technologies for increasing the chances of conceiving a boy.

Meanwhile the killing of baby girls using traditional methods - such as poisoning with plant extracts or putting opium on the nipples of nursing mothers - continues to be used in poor regions such as Tamil Nadu and Rajasthan. According to some reports, about 6,000 baby girls have died of poisoning over the past ten years in one small community in Tamil Nadu. The government is now looking at ways of dealing with female infanticide.

K. S. Jayaraman
While NSERC grants are awarded to individual researchers, FCAR grants are the responsibility of the organization to which the applicant is affiliated.

The audit report found that research grant funds "were diverted to uses other than those permitted under the rules, and that costs associated with specific contracts were not properly matched against the revenue from those contracts - and vice-versa".

It said that a combination of university procedures and a "thoroughly confusing computerized accounting system" made it impossible for either the university treasury or its office of research services to ensure that grantors' rules were being adequately followed.

The report claimed that many researchers and teachers in the engineering and computer science faculty "participated in a deliberate scheme to manipulate account balances, transfer amounts of money, comingle research grants with contract funds and divert them to discretionary research accounts". All this had been done "in the interest of promoting research", and defended on the basis that the funds were "intended to be used in research anyway".

In some cases, grants and contracts had been charged for personnel and facilities whose cost was already absorbed by the university's operating budget. The resulting revenue went either into accounts held under the discretionary control of the dean, or to other department heads.

Conflicts of interest were also discovered by the FCAR report. In one case, a professor had calculated that he could spend up to 190 days a year working as a consultant to outside bodies -15 more than he worked for the university.

The report said a "climate of pressure" existed at Concordia. This included pressure from the administration to maximize grants and contracts, which influenced faculty members' evaluation for appointments, tenure and promotion; pressure from peers to break new ground in research; and pressure from granting agencies to compete for funds. This pressure, it said, was "so intense that it overwhelms and blurs the vision of even those not directly benefiting from the improprieties".

David Spurgeon

\section{Correction: European Patent Office}

In the article "A moral question for patent legislation" (Nature 369, 589; 1994), part of the explanation of the "Inventive step" (column 1) was ambiguous. The second sentence of this section should have read: "The EPO will want to be satisfied that ... the invention involves the exercise of ability beyond that to be expected of the person 'skilled in the art'."

Second, the caption to the chart under the heading "Recession hits European patents" (Nature 369, $694 ; 1994)$, should have referred to the distribution of patents applied for - not awarded - at the EPO. 